\title{
Bmoo FIBMP-I: A New Fibrinogenolytic Metalloproteinase from Bothrops moojeni Snake Venom
}

\author{
F. S. Torres, ${ }^{1}$ B. Rates, ${ }^{1}$ M. T. R. Gomes, ${ }^{2}$ C. E. Salas, ${ }^{2}$ A. M. C. Pimenta, ${ }^{1}$ F. Oliveira, ${ }^{3,4}$ \\ M. M. Santoro, ${ }^{5}$ and M. E. de Lima ${ }^{1}$ \\ ${ }^{1}$ Laboratório de Venenos e Toxinas Animais, Departamento de Bioquímica e Imunologia, Instituto de Ciências Biológicas, \\ Universidade Federal de Minas Gerais, 31270-901 Belo Horizonte, MG, Brazil \\ ${ }^{2}$ Laboratório de Biologia Molecular de Produtos Naturais, Departamento de Bioquímica e Imunologia, Instituto de Ciências Biológicas, \\ Universidade Federal de Minas Gerais, 31270-901 Belo Horizonte, MG, Brazil \\ ${ }^{3}$ Departamento de Ciências Fisiológicas, Instituto de Ciências Biomédicas, Universidade Federal de Uberlândia, \\ 38400-902 Uberlândia, MG, Brazil \\ ${ }^{4}$ Instituto Nacional de Ciência e Tecnologia em Nano-Biofarmacêutica (N-Biofar), Belo Horizonte, MG, Brazil \\ ${ }^{5}$ Laboratório de Físico-Química de Proteínas e Enzimologia, Departamento de Bioquímica e Imunologia, \\ Instituto de Ciências Biológicas, Universidade Federal de Minas Gerais, 31270-901 Belo Horizonte, MG, Brazil
}

Correspondence should be addressed to M. E. de Lima, melenalima@icb.ufmg.br

Received 24 August 2012; Accepted 8 October 2012

Academic Editors: A. Cruz, F. Ducancel, and Y. N. Utkin

Copyright (C) 2012 F. S. Torres et al. This is an open access article distributed under the Creative Commons Attribution License, which permits unrestricted use, distribution, and reproduction in any medium, provided the original work is properly cited.

\begin{abstract}
A new fibrinogenolytic metalloproteinase (Bmoo FIBMP-I) was purified from Bothrops moojeni snake venom. This enzyme was isolated through a combination of three chromatographic steps (ion-exchange, molecular exclusion, and affinity chromatography). Analyses by reverse phase chromatography, followed by mass spectrometry, showed the presence of enzyme isoforms with average molecular mass of $22.8 \mathrm{kDa}$. The SDS-PAGE analyses showed a single chain of $27.6 \mathrm{kDa}$, in the presence and absence of reducing agent. The protein has a blocked N-terminal. One of the peptides obtained by enzymatic digestion of a reduced and S-alkylated isoform was completely sequenced by mass spectrometry (MS/MS). Bmoo FIBMP-I showed similarity with hemorrhagic factor and several metalloproteinases (MP). This enzyme degraded A $\alpha$-chain faster than the $\mathrm{B} \beta$-chain and did not affect the $\gamma$-chain of bovine fibrinogen. The absence of proteolytic activity after treatment with EDTA, together with the observed molecular mass, led us to suggest that Bmoo FIBMP-I is a member of the P-I class of the snake venom MP family. Bmoo FIBMP-I showed pHdependent proteolytic activity on azocasein, but was devoid of coagulant, defibrinating, or hemorrhagic activities. The kinetic parameters of proteolytic activity in azocasein were determined $\left(V_{\max }=0.4596 \mathrm{Uh}^{-1} \mathrm{nmol}^{-1} \pm 0.1031 \mathrm{and} K_{m}=14.59 \mathrm{mg} / \mathrm{mL} \pm\right.$ 4.610).
\end{abstract}

\section{Introduction}

Snake venoms are complex mixtures of proteins and peptides with diverse pharmacological activities. A number of these proteins have direct action on vessels walls, platelet function, fibrinogen, and other factors of the hemostatic system $[1,2]$. While neurotoxicity is the most pronounced effect of envenomation by snakes from the Elapidae family, envenomation by snakes from the Viperidae family is usually characterized by local and, in severe cases, systemic effects $[3,4]$. These snake venoms are rich sources of metalloproteinases (MPs) which, along with the transmembrane ADAMS (desintegrin-like and metalloproteinase-containing proteins), are members of the reprolysins subfamily M12-family of metalloproteinases. (Snake venom metalloproteinases) SVMPs have been classified into three basic structural classes, P-I to P-III [57]. These metalloproteinases are synthesized in the venom gland as large multidomain proteins, including a proenzyme domain and a highly conserved zinc-proteinase domain (HEBXHXBGBXH) $[6,8,9]$.

The P-I (PIa) metalloproteinase class includes proteins with molecular masses between $20-30 \mathrm{kDa}$ that have 
low or no hemorrhagic effect, but strong direct-acting fibrino(geno)lytic activity, and contain only a metalloproteinase domain. Class P-II (P-IIa, P-IIb, P-IIc, P-IId, and PIIe) comprises proteins with molecular masses of $30-60 \mathrm{kDa}$ that contain metalloproteinase and disintegrin-like domains. Class P-III (P-IIIa, P-IIIb, P-IIIc, and P-IIId) includes a cysteine-rich domain, a melloproteinase domain, and a disintegrin-like and a lectin-like domain $[2,5,7]$.

Many proteinases have been purified and characterized from venoms of different Bothrops species such as: Bothrops jararaca [10-12], Bothrops moojeni [13-18], Bothrops neuwiedi [19-21], Bothrops leucurus [2, 22, 23], Bothrops jararacussu [24-26], Bothrops asper [27, 28], Bothrops cotiara [29].

This paper reports the isolation and partial characterization of a fibrinogenolytic metalloproteinase, Bmoo FIBMP-I, from $B$. moojeni snake venom.

\section{Materials and Methods}

2.1. Materials. Desiccated B. moojeni venom was purchased from Bioagents Serpentarium (Batatais-SP, Brazil). Acrylamide, ammonium persulfate, aprotinin, benzamidine, bromophenol blue, ethylenediaminetetracetic acid (EDTA), bovine fibrinogen, $\beta$-mercaptoethanol, $N, N^{\prime}$-methylenebis-acrylamide, sodium dodecyl sulphate (SDS) $N, N, N^{\prime}, N^{\prime}$ tetramethylethylenediame (TEMED), glycine, Tris, molecular weight markers for electrophoresis, and all chromatographic media were purchased from Sigma Chemical Co. (St. Louis, MO, USA). All other reagents used were of analytical grade.

2.2. Isolation of the Metalloproteinase Bmoo FIBMP-I. The chromatographic steps were based on a previously published protocol with minor modifications $[16,30]$. The crude venom of $B$. moojeni $(250 \mathrm{mg})$ was dissolved in $0.05 \mathrm{M}$ ammonium bicarbonate buffer $(\mathrm{pH} 7.8)$ and clarified by centrifugation at $10,000 \mathrm{~g}$ for $10 \mathrm{~min}$ at room temperature. The clear supernatant solution was applied to a DEAE Sephacel column $(2 \times 12 \mathrm{~cm})$, previously equilibrated with $0.05 \mathrm{M}$ ammonium bicarbonate buffer $\mathrm{pH} 7.8$ and eluted with a concentration gradient $(0.05 \mathrm{M}-0.3 \mathrm{M})$ of the same buffer. Fractions of $3.0 \mathrm{~mL} /$ tube were collected and their absorbances were read at $280 \mathrm{~nm}$. The fourth fraction, named D4, was pooled, lyophilized, dissolved in $0.05 \mathrm{M} \mathrm{pH}$ 7.8 ammonium bicarbonate, and applied to a Sephadex G-75 column $(1 \times 120 \mathrm{~cm})$ previously equilibrated with the same buffer. The fibrinogenolytic fraction (D4G2) was lyophilized and applied to a column of Heparin Agarose $(2 \times 10 \mathrm{~cm})$ previously equilibrated with $0.01 \mathrm{M} \mathrm{pH} \mathrm{7.5} \mathrm{Tris-} \mathrm{HCl}$ buffer, containing $0.05 \mathrm{M} \mathrm{CaCl}_{2}$ and eluted with $0.01 \mathrm{M} \mathrm{pH} 7$ Tris$\mathrm{HCl}$ buffer containing $1 \mathrm{M} \mathrm{NaCl}$. The flow rate was $40 \mathrm{~mL} / \mathrm{h}$ and fractions of $2.0 \mathrm{~mL}$ were collected.

\subsection{Reversed Phase HPLC of the Purified Metalloproteinase} Bmoo FIBMP-I. The fraction showing fibrinogenolytic and azocaseinolytic activities, obtained in the previous step, was submitted to reverse phase system on a Source 15RPC column $(0.46 \mathrm{~cm} \times 25 \mathrm{~cm})$, ÄKTA Explorer, AmershamPharmacia (Uppsala, Sweden), equilibrated with the eluent A $(0.1 \%$ TFA in water Milli-Q), eluted by linear gradient (from 0 to $60 \%$ in $50 \mathrm{~min}$, and from 60 to $100 \%$ in $7.5 \mathrm{~min}$ ) of eluent B (acetonitrile, $0.1 \% \mathrm{TFA}$ ) at a flow rate of $2 \mathrm{~mL} / \mathrm{min}$, and monitored by absorbance at $280 \mathrm{~nm}$.

2.4. Biochemical Characterization. The protein concentration of the venom samples and fractions was determined by the method of microbiuret, as described by Itzhaki and Gill [31], using bovine serum albumin as standard. Polyacrylamide gel electrophoresis was performed in the presence of sodium dodecyl sulfate (SDS-PAGE) and carried out according to a previously described method [32] using 14\% gels. Samples were pretreated under reducing conditions (SDS plus $\beta$-mercaptoethanol) at $100^{\circ} \mathrm{C}$ for $5 \mathrm{~min}$. Gels were stained with $0.1 \%$ Coomassie brilliant blue R-250 in ethanol: acetic acid $(5: 1, \mathrm{v} / \mathrm{v})$ for $15 \mathrm{~min}$ and distained in $10 \%$ acetic acid: water $(\mathrm{v} / \mathrm{v})$. The molecular mass was estimated by interpolation from a linear logarithmic plot of relative molecular mass versus distance of migration. Standard molecular weight markers (Sigma) were b phosphorylase $(97 \mathrm{kDa})$, bovine serum albumin $(66 \mathrm{kDa})$, egg albumin $(45 \mathrm{kDa})$, carbonic anhydrase $(30 \mathrm{kDa})$, soybean trypsin inhibitor $(20.1 \mathrm{kDa})$, and lactoalbumin $(14.4 \mathrm{kDa})$.

2.5. Sequence Analysis. The protein $(0.3 \mathrm{mg})$ was reduced and S-alkylated as previously described $[33,34]$. The sample containing the protein was dissolved in $1 \mathrm{~mL}$ of $0.6 \mathrm{M}$ Tris$\mathrm{HCl}$ buffer containing $6 \mathrm{M}$ guanidine, $\mathrm{pH} 8.6$, and $30 \mu \mathrm{L}$ of $\beta$-mercaptoethanol (pure liquid 14.3 M), under nitrogen atmosphere, and incubated at $50^{\circ} \mathrm{C}$ for $5 \mathrm{~h}$. Then, $20 \mu \mathrm{L}$ of 4 -vinylpiridine $(95 \%)$ were added and the samples were incubated at $37^{\circ} \mathrm{C}$ during $1.5 \mathrm{~h}$. The protein was recovered by desalting on a Vydac C4 column $(0.46 \mathrm{~cm} \times 25 \mathrm{~cm})$ using a gradient of 0 to $100 \%$ acetonitrile in $0.1 \%$ TFA at a flow rate of $2 \mathrm{~mL} / \mathrm{min}$. The proteins were detected by their absorbance at $216 \mathrm{~nm}$. For digestion, the reduced/Salkylated protein $(0.2 \mathrm{mg})$ was dissolved in $100 \mu \mathrm{L}$ of $8 \mathrm{M}$ urea and diluted to $900 \mu \mathrm{L}$ with $0.1 \mathrm{M} \mathrm{NH}_{4} \mathrm{HCO}_{3}, \mathrm{pH}$ 8.1 , then digested with trypsin $(5 \% \mathrm{w} / \mathrm{w}$, enzyme/protein, for $4 \mathrm{~h}$ at $37^{\circ} \mathrm{C}$ ). The obtained peptides were purified by reverse phase HPLC on a Vydac C4 column using extended $(\sim 4 \mathrm{~h})$ linear gradient of $0-70 \%$ acetonitrile in $0.1 \%$ TFA. The peptides purified were then sequenced using MS/MS in MALDI-TOF/TOF MS Autoflex III (Bruker Daltonics, Germany). The primary sequences of the obtained peptides were compared to sequences of other related proteins in the SWISS-PROT/TREMBL data base using FASTA 3 and BLAST programs.

\subsection{Enzymatic Activities}

2.6.1. Proteolytic Activity upon Fibrinogen. The fibrinogenolytic activity was assayed as described by Edgar and Prentice [35], partially modified. Five micrograms of the enzyme were added to $50 \mu \mathrm{L}$ of bovine fibrinogen $(1.5 \mathrm{mg} / \mathrm{mL})$, buffered at different pHs (0.02 M sodium acetate buffer, $\mathrm{pH} 3,4$, and 5; $0.02 \mathrm{M}$ sodium phosphate buffer, $\mathrm{pH}$ 6; $0.02 \mathrm{M}$ Tris- $\mathrm{HCl}$ 
buffer, $\mathrm{pH} 7,8$, and 9.0; sodium borate buffer, $\mathrm{pH} 10$ and 11) at $37^{\circ} \mathrm{C}$ for $60 \mathrm{~min}$. The reaction was stopped by addition of $25 \mu \mathrm{L}$ of $0.05 \mathrm{M}$ Tris- $\mathrm{HCl}$ buffer, $\mathrm{pH}$ 8.8, containing $10 \%$ $(\mathrm{v} / \mathrm{v})$ glycerol, $10 \%(\mathrm{v} / \mathrm{v}) \beta$-mercaptoethanol, $2 \%(\mathrm{w} / \mathrm{v})$ SDS, and $0.05 \%(\mathrm{w} / \mathrm{v})$ bromophenol blue. The reaction products were then analyzed by $14 \%(\mathrm{w} / \mathrm{v})$ SDS-PAGE.

To determine the effect of temperature on the fibrinogenolytic activity, $5 \mu \mathrm{g}$ of enzyme $(0.02 \mathrm{M}$ Tris- $\mathrm{HCl}$ buffer $\mathrm{pH} 9.0)$ were incubated at different temperatures $(40,50$, 60,70 , and $80^{\circ} \mathrm{C}$ ) for $15 \mathrm{~min}$ before chilling in ice bath for $5 \mathrm{~min}$. Then, the fibrinogenolytic activity was determined as described above.

The effect of inhibitors on the fibrinogenolytic activity was assayed after preincubation of the enzyme $(5 \mu \mathrm{g})$ dissolved in $0.25 \mathrm{~mL}$ of $0.05 \mathrm{M}$ Tris- $\mathrm{HCl}$ buffer, $\mathrm{pH} 8.0$, with $10 \mathrm{mM}$ EDTA (metalloproteinase inhibitor) or $0.01 \mathrm{M}$ aprotinin (serinoproteinase inhibitor) for $30 \mathrm{~min}$ at room temperature.

2.6.2. Hemorrhagic, Coagulant, and Defibrinating Activities. The possible haemorrhagic, coagulant, and defibrinating activities of Bmoo FIBMP-I were investigated. Hemorrhagic activity was assessed by the method of Kondo et al. [36]. Briefly, different doses of the purified enzyme $(1-10 \mu \mathrm{g})$, in $100 \mu \mathrm{L}$ of $0.9 \% \mathrm{NaCl}$ were intradermally injected into the dorsal skin of male Swiss mice (18-22 g). After $24 \mathrm{~h}$, the animals were anesthetized with ether and killed. Skins were removed and the areas of hemorrhage on their inner surfaces were scanned above a sheet of white paper. The area of each halo was cut out and its mass was measured in a precision scale. The hemorrhage was calculated through a previously determined correlation of the area of the white paper with its respective mass $\left(7.5 \mathrm{mg} / \mathrm{cm}^{2}\right)$. The minimum hemorrhagic dose (MHD) is defined as the dose of protein wich results in an hemorrhagic lesion of $1.0 \mathrm{~cm}^{2}$ after $24 \mathrm{~h}$.

The coagulant activity of the enzyme was assayed as described by Thekston and Reid [37]. The minimum coagulant dose (MCD) is defined as the minimum amount of enzyme that clots bovine plasma (MCD-P) and/or a solution of bovine fibrinogen $(2.0 \mathrm{mg} / \mathrm{mL}$; MCD-F) in 60 seconds at $37^{\circ} \mathrm{C}$. The defibrinating activity was tested by the method of Gené et al. [38], with minor modifications. The activity was assessed by intraperitoneal injection of different doses of the enzyme $(20-100 \mu \mathrm{g})$, in $100 \mu \mathrm{L}$ of saline solution $(0.9 \%$ $\mathrm{NaCl}$ ), into male Swiss mice (18-22 g), using four mice per group at each protein dose; control animals received $200 \mu \mathrm{L}$ of saline solution. One hour after, the animals were anesthetized and bled by cardiac puncture. Whole blood was placed in tubes and kept at $25-30^{\circ} \mathrm{C}$ until clotting occurred. The minimum defibrinating dose (MDD) was defined as the amount of venom able to prevent coagulation.

2.6.3. Proteolytic Activity on Azocasein (Azocaseinolytic Activity). The proteolytic activity was quantified by the method of Leonardi et al. [39], with modifications. Several concentrations $(20,40,60$ and $80 \mu \mathrm{g})$ of Bmoo FIBMP-I were added to $500 \mu \mathrm{L}$ of an azocasein solution $(1 \mathrm{mg} / \mathrm{mL}$ in $0.2 \mathrm{M}$ Tris$\mathrm{HCl}$ buffer, $\mathrm{pH} 8.8$, containing $0.004 \mathrm{M} \mathrm{CaCl}_{2}$ ), at $37^{\circ} \mathrm{C}$ for $60 \mathrm{~min}$. The reaction was interrupted by the addition of $5 \%$ trichloroacetic acid (TCA) and then centrifuged $(14,000 \mathrm{~g}$, $10 \mathrm{~min}$ ). The absorbance of the supernatant was read at $366 \mathrm{~nm}$. One unit of proteolytic activity corresponds to an increase of 0.1 unit at $A_{366}$. The influence of $\mathrm{pH}$ on proteolytic activity was also tested by preincubation of the enzyme fraction in various buffers at different $\mathrm{pH}(0.02 \mathrm{M}$ sodium acetate buffer, $\mathrm{pH} 3,4$, and $5 ; 0.02 \mathrm{M}$ sodium phosphate buffer, $\mathrm{pH} 6,0 ; 0.02 \mathrm{M}$ Tris-HCl buffer, $\mathrm{pH} \mathrm{7,} \mathrm{8,}$ and 9.0; sodium borate buffer, $\mathrm{pH} 10$ and 11 ) at $37^{\circ} \mathrm{C}$ for $60 \mathrm{~min}$.

2.7. Kinetic Analyses. The steady-state parameters $K_{m}$ and $V_{\max }$ were determined from initial rate measurements at various azocasein concentrations in $0.2 \mathrm{M}$ Tris- $\mathrm{HCl}$ buffer, $\mathrm{pH}$ 8.8, containing $0.004 \mathrm{M} \mathrm{CaCl}_{2}$ at $25^{\circ} \mathrm{C}$. At least two separate measurements were carried out for each azocasein concentration. Reactions were initiated by the addition of appropriate limiting amounts of enzymes and the formation of cleavage products was monitored at $366 \mathrm{~nm}$. The normalized velocity was calculated using the conversion factor 1.578. This conversion factor was obtained by multiplying the number of hours ( 6 hours) by the molar mass of the protein $(2.63 \mathrm{nmoL})$ and the number of activity units of the enzyme (every enhancement of 0.1 in the absorbance equals to 1 activity unit). The Michaelis constant $K_{m}$ and $V_{\max }$ were determined by analysis of Michaelis Menten constant plot of the normalized velocity as a function of substrate concentration.

2.8. Mass Spectrometry and Data Analyses. ESI-Q-TOF mass spectrometry analyses were carried out using a Q-TOF Micro (Micromass, UK) equipped with an electrospray ionization source operated in the positive mode. The capillary voltage was $2.5-3.0 \mathrm{kV}$ and the sample cone voltages were 30 $40 \mathrm{~V}$. Mass spectrometer calibrations were made by using sodium iodide in 100 to $2000 \mathrm{~m} / \mathrm{z}$. Samples diluted in $50 \%$ acetonitrile/0.1\% TFA were introduced by using a syringe pump with a flow rate of $10 \mu \mathrm{L} / \mathrm{min}$. Original data $(\mathrm{m} / \mathrm{z})$ were treated (base line subtraction, smoothing, and centering) and transformed into a mass (Da) spectrum. Data analyses were carried out using MassLynx 4.0 software.

Other analyses, MS and tandem MS, analysis were performed using a MALDI-TOF-TOF AutoFlex III (Bruker Daltonics) instrument in positive/reflector mode controlled by the Flex-Control software. Instrument calibration was achieved by using Peptide Calibration Standard II (Bruker Daltonics) as reference and $\alpha$-cyano-4-hydroxycinnamic acid as matrix. Samples were spotted to MTP AnchorChip 400/384 (Bruker Daltonics) targets using standard protocols for the dried droplet method.

MS data analyses were performed by using the FlexAnalysis software (Bruker Daltonics). Peptide de novo sequencing was performed using a combination of manual and automatic data interpretation using the softwares FlexAnalysis and BioTools (Bruker Daltonics). Alternatively, MS/MS data were exported as *.txt files and then converted to the *.dta extension. Then such files were imported into *.psq files which are recognizable by the PepSeq (Micromass, 
TABLE 1: Summary of the chromatographic steps of the Bmoo FIBMP-I enzyme from Bothrops moojeni.

\begin{tabular}{lcccc}
\hline Sample & Total protein $(\mathrm{mg})$ & Protein recovery $(\%)$ & Total activity (units) & Specific activity** \\
\hline Crude venom & 242.0 & 100 & 35,62 & 147 \\
D4 & 27.38 & 11.31 & 8,310 & 303 \\
D4G2 & 12.06 & $5\left(44.04^{1}\right)$ & 4,544 & 377 \\
Bmoo FIBMP-I & 7 & $2.9\left(58.03^{2}\right)$ & 4,601 & 657 \\
\hline
\end{tabular}

*Proteolytic activity was tested with azocasein as substrate.

$* *$ One unit of specific activity was defined as units/mg protein.

${ }^{1}$ Protein recovery related to fraction D4.

${ }^{2}$ Protein recovery related to fraction $\mathrm{D} 4 \mathrm{G} 2$.

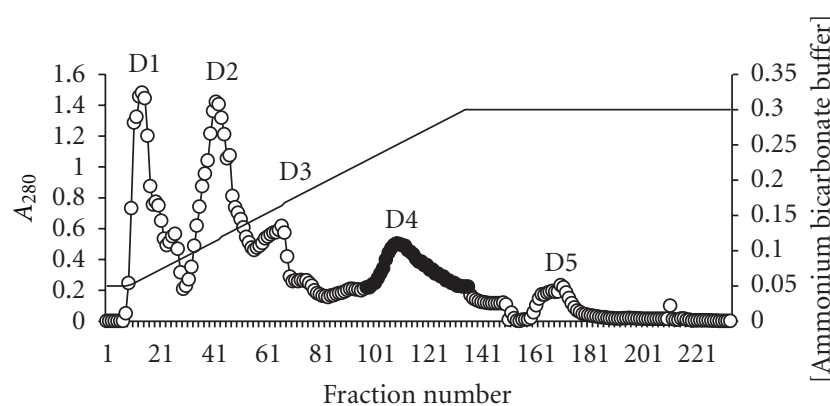

(a)

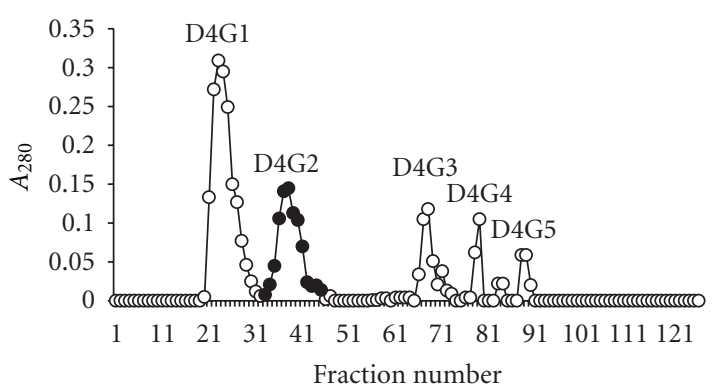

(b)

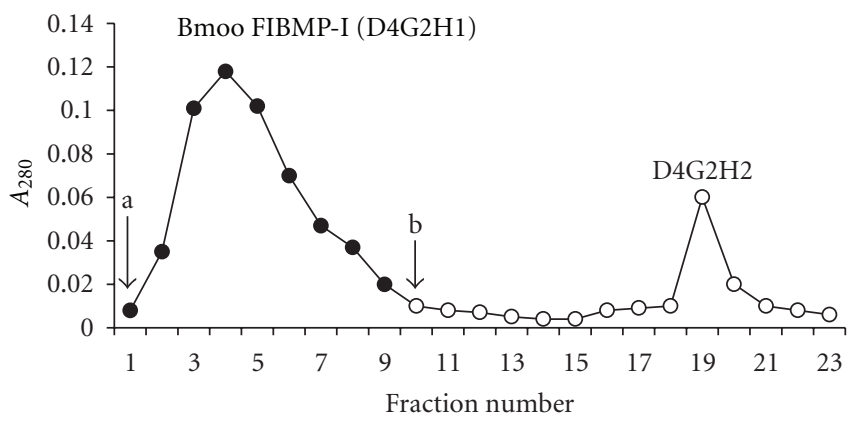

(c)

Figure 1: Purification of Bmoo FIBMP I from Bothrops moojeni venom. (a) Ion-exchange chromatography of Brazilian B. moojeni venom on DEAE Sephacel. The fibrinogenolytic activity was greater in fraction D4. (b) Gel filtration on Sephadex G-75 column. Fibrinogenolytic and azoproteolytic activities were observed for D4G2 fraction. (c) Affinity chromatography on Heparine Agarose resin. Fibrinogenolytic and azoproteolytic activities were observed for fraction Bmoo FIBMP-I. • Fibrinogenolytic activity (fractions pooled).

UK) software which was also used for manual de novo sequencing. Similarity searches were performed with the obtained sequences using the Fasta3 tool against the SwissProt data Bank, as previously described [40].

\section{Results and Discussion}

The high proteolytic activity of Bothrops snake venoms is primarily responsible for most of the local and systemic effects observed during envenomation by these snakes [1]. This activity is caused by a variety of enzymes, for example, metalloproteinases, which are enzymes that possess a metal ion at the active site and are responsible for the bleeding that results from Bothrops bites [25, 41]. Thus, in this study, the interest was focused on this group of molecules.

The purification of the fibrinogenolytic enzyme Bmoo FIBMP-I from B. moojeni venom consisted of a three-step procedure including ion-exchange on DEAE Sephacel, gel filtration on Sephadex G-75, and affinity chromatography on Heparine-Agarose. Five protein fractions displaying $\mathrm{A}_{280}$ (D1, D2, D3, D4, and D5) were obtained when the crude venom was applied onto the DEAE Sephacel column $(2.0 \mathrm{~cm} \times 12.0 \mathrm{~cm})$, as shown in Figure $1(\mathrm{a})$. The $\mathrm{pH}$ used in this chromatographic step was 7.8 , which is considered to be the optimum $\mathrm{pH}$ for the activity of most proteolytic enzymes already isolated from snake venoms [42-47]. The fibrinogenolytic activity was found in all the UV-absorbing fractions, but the highest activity was found in D4 fraction. This fraction was pooled, lyophilized, and used in the second step of purification on Sephadex G-75 column $(1.0 \mathrm{~cm} \times$ $120.0 \mathrm{~cm}$ ), equilibrated with $0.05 \mathrm{M}$ ammonium bicarbonate buffer, $\mathrm{pH}$ 7.8. In this step, D4 fraction was resolved in five fractions named D4G1, D4G2, D4G3, D4G4, and D4G5 (Figure 1(b)). 


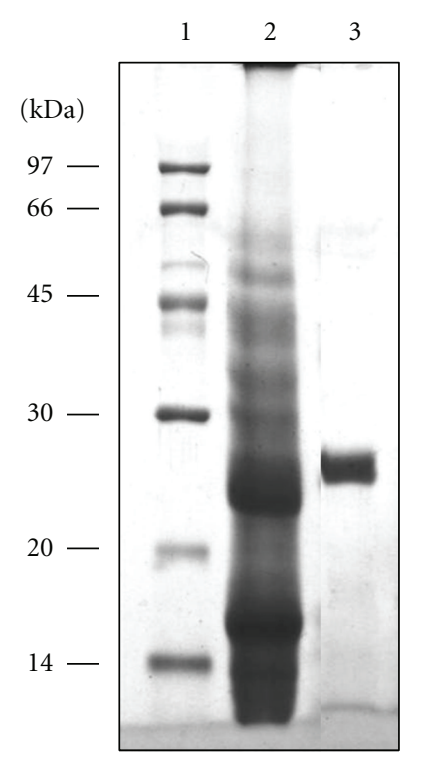

FIGURE 2: SDS PAGE electrophoresis of the crude venom and purified fibrinogenolytic enzyme from B. moojeni in $14 \%(\mathrm{w} / \mathrm{v})$ polyacrylamide gel. Line 1: molecular mass standards. Line 2: reduced crude B. moojeni venom $(50 \mu \mathrm{g})$. Line 3: reduced Bmoo FIBMP-I $(40 \mu \mathrm{g})$.

The D4G2 fraction, which displayed fibrinolytic and azoproteolytic activities, was further purified on HeparineAgarose Type I $(2.0 \mathrm{~cm} \times 10 \mathrm{~cm})$ column, equilibrated with $0.02 \mathrm{M}$ Tris- $\mathrm{HCl}$ buffer containing $5.0 \mathrm{mM} \mathrm{CaCl}_{2}$, and eluted with the same buffer until the tenth tube and then with $0.02 \mathrm{M}$ Tris- $\mathrm{HCl}$ buffer containing $1.0 \mathrm{M}$ $\mathrm{NaCl}$. Two fractions (D4G2H1 and D4G2H2) were resolved (Figure 1(c)). D4G2H1 displayed fibrinogenolytic and azoproteolytic activities. Its specific activity was $657 \mathrm{U} / \mathrm{mg}$, and this fraction was called Bmoo FIBMP-I, as shown in Table 1.

The protein yield, based on the absorbance at $280 \mathrm{~nm}$, was $7.0 \mathrm{mg}$ for D4G2H1 (Bmoo FIBMP-I) fraction. The enzyme represents $2.9 \%$ of the total protein in the venom (Table 1). The yield of Bmoo FIBMP-I was higher than those reported for other fibrinogenolytic enzymes purified from the same venom, for example, MSP1, MSP2 [15], and MOO3 [46] that yielded $0.51,1.1$, and $1.42 \%$, respectively.

Bmoo FIBMP-I was apparently homogeneous and migrated as a single band of a molecular mass estimated as $27.6 \mathrm{kDa}$ by SDS-PAGE under reducing (Figure 2, lane 3 ) and native (data not shown) conditions.

For best characterization, Bmoo FIBMP-I was applied onto an HPLC system using a reverse phase chromatography SOURCE column $(0.46 \mathrm{~cm} \times 25 \mathrm{~cm})$, equilibrated with solution A ( $0.1 \%$ TFA in water), and eluted with a gradient of solutions A and B (0.1\% TFA in acetonitrile). Two major fractions were obtained (Bmoo FIBMP-I H1 and Bmoo FIBMP-I H2) (Figure 3) that did not show fibrinogenolytic or azocaseinolytic activities, as expected. We believe that the loss of activity was due to the presence of the organic solvent acetonitrile. Both collected fractions were submitted to mass spectrometry analyses, showing molecular masses of
TABLE 2: Sequencing de novo of Bmoo FIBMP-I peptides. Similarity searches were performed with the obtained sequences using the Fasta3 tool against the Swiss-Prot data Bank.

\begin{tabular}{lc}
\hline Peptide mass $(\mathrm{Da})$ & Sequence \\
\hline 817,4044 & NSINTLR \\
1175,4693 & AYTGGMCDPR \\
1319,6585 & TDQVNEDFVPR \\
1432,6530 & ASGGQGGLELWSDR \\
1721,7799 & YIELVVVADHGMFTK \\
\hline
\end{tabular}

$22.7 \mathrm{kDa}$ and $22.9 \mathrm{kDa}$, respectively (data not shown). Both proteins are, most likely, isoforms with slight difference in their amino acid residues. The presence of protein isoforms is a common feature found in samples of proteases isolated from snake venoms $[48,49]$.

Bmoo FIBMP-I was resistant to cleavage by Edman Nterminal sequencing, suggesting that its $\mathrm{N}$-terminal residue could be blocked by the presence of piroglutamic residue, a common feature in proteases from snake venoms, as demonstrated for a fibrinogenolytic protease of Bothrops leucurus venom described by Bello et al. [2] and confirmed by Ferreira et al. [50].

The partial amino acid sequence (de novo sequencing) of Bmoo FIBMP-I was manually established by analyzing the MS/MS data in MALDI TOF TOF of peptides resulting from trypsin digestions (Table 2). As shown in Table 3, the data indicate that one of the tryptic fragments whose sequence is YIELVVVADHGMFTK $(1,721 \mathrm{Da})$ shares homology with metalloproteinases of different snake venoms as, for example, a MP from Bothrops moojeni, BmooMP $\alpha$-I [16], a MP from Agkistrodon halys pallas [51], and an hemorraghic factor from Lachesis muta muta (Bushmaster) [52].

The classes of MP from snake venoms are differentiated by the size and the presence of structural domains in addition to the metalloproteinase domain. These classes are named PI to PIII, with molecular masses ranging from 15 to $100 \mathrm{kDa}$ $[6,53]$. PI class contains exclusively the metalloproteinase domain and possess molecular mass around $25 \mathrm{kDa}$, with or without hemorrhagic effects [54]. It is divided into two subclasses: P-1A, formed by proteins as BthMP from $B$. moojeni venom [17], and P-1B, for example, Neuwidase from B. neuwiedi venom $[19,21]$. Bmoo FIBMP-I showed high fibrinogenolytic and azoproteolytic activities, although its coagulant, anticoagulant, and haemorrhagic activities were absent. Thus, we suggest that Bmoo FIBMP-I is a PI-B class of metalloproteinase by considering its molecular mass of $22.8 \mathrm{kDa}$ and the absence of hemorrhagic activity.

The structure of fibrinogen is composed of three pairs of disulphide-linked chains termed $\mathrm{A} \alpha, \mathrm{B} \beta$, and $\gamma$ chains. Following vascular injury, there are two principal mechanisms involving fibrinogen to control bleeding. It acts as an adhesive protein essential for platelet aggregation as well as forming an insoluble fibrin clot in the final stage of the blood coagulation cascade [55]. The action of proteinases that may interfere with coagulation and the fibrino(geno)lytic system following envenomation by Bothrops snake bites have been reported [53]. 


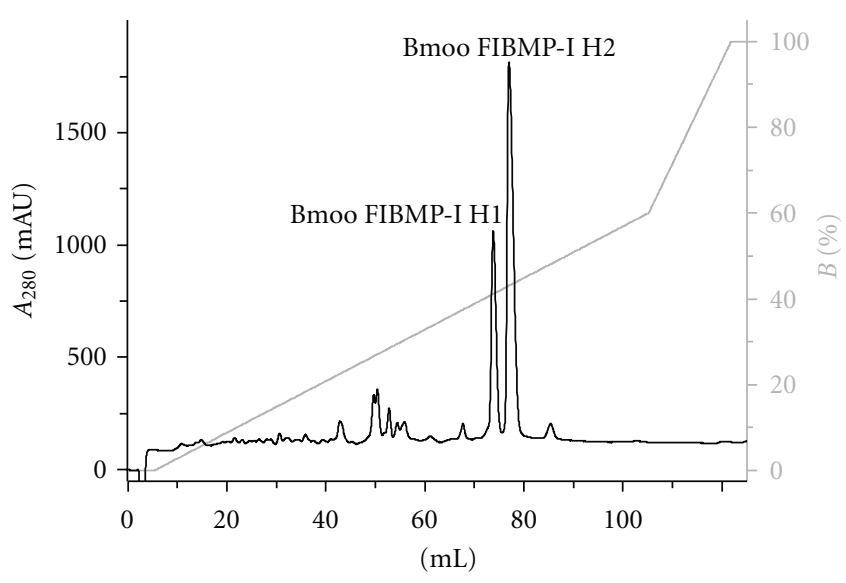

Figure 3: Reverse phase chromatography of Bmoo FIBMP-I. The fractions Bmoo FIBMP-I H1 and Bmoo FIBMP-I H2 did not show fibrinogenolytic or azocaseinolytic activities.

TABle 3: Similarities with the $1.72 \mathrm{kDa}$ peptide from Bmoo FIBMP-I. AGKHP Metalloproteinase from Agkistrodon halys pallas (482 aa) (UNIPROT Q9PVK9_AGKHP [78]). LACMU hemorrhagic factor II from Lachesis muta muta (Bushmaster) (200 aa) (UNIPROT HRL2_LACMU [52]). Bmoo MP $\alpha$-I Metaloproteinase from Bothrops moojeni (UNIPROT VM1BI_BOTMO [16]). AGKHB metaloproteinase (fragment) from Agkistrodon halys (UNIPROT Q90WC0_AGKHB [51]).

\begin{tabular}{|c|c|c|c|c|c|c|c|c|c|c|c|c|c|c|c|c|c|c|}
\hline Protein & $\mathrm{AA}$ & & & & & & & & ienc & & & & & & & & Similarity (\%) & PDB \\
\hline Bmoo FIBMP-I & - & $\mathrm{Y}$ & I & $\mathrm{E}$ & $\mathrm{L}$ & $\mathrm{V}$ & $\mathrm{V}$ & $\mathrm{V}$ & $\mathrm{A}$ & $\mathrm{D}$ & $\mathrm{H}$ & G & M & $\mathrm{F}$ & $\mathrm{T}$ & $\mathrm{K}$ & & \\
\hline AGKHP & $198-212$ & $\mathrm{Y}$ & I & $\mathrm{E}$ & $\mathrm{L}$ & V & V & $\mathrm{V}$ & A & $\mathrm{D}$ & $\mathrm{H}$ & G & M & $\mathrm{F}$ & $\mathrm{T}$ & $\mathrm{K}$ & 100 & Q9PVK9 \\
\hline LACMU & 5-19 & $\mathrm{Y}$ & I & $\mathrm{E}$ & $\mathrm{L}$ & V & V & $\mathrm{V}$ & A & $\mathrm{D}$ & $\mathrm{H}$ & G & M & $\mathrm{F}$ & $\mathrm{T}$ & $\mathrm{K}$ & 100 & HRL2 \\
\hline $\operatorname{Bmoo~} \mathrm{MP} \alpha-\mathrm{I}$ & $9-23$ & $\mathrm{Y}$ & I & $\mathrm{E}$ & $\mathrm{L}$ & $\mathrm{V}$ & $\mathrm{V}$ & V & A & $\mathrm{D}$ & $\mathrm{H}$ & G & M & $\mathrm{F}$ & K & $\mathrm{K}$ & 97.8 & VM1BI \\
\hline AGKHB & $33-47$ & Y & I & E & $\mathrm{L}$ & V & I & $\mathrm{V}$ & A & $\mathrm{D}$ & $\mathrm{H}$ & G & M & $\mathrm{F}$ & $\mathrm{T}$ & K & 97.8 & Q90WC0 \\
\hline
\end{tabular}

The majority of the fibrinogenolytic enzymes in snake venoms are classified as "metzincins", as described by Stocker et al. [56] and preferentially cleave the A $\alpha$ chain of bovine fibrinogen with a slower cleavage of $\mathrm{B} \beta$ chain $[57,58]$.

Bmoo FIBMP-I rapidly digested the $\mathrm{A} \alpha$-chain of bovine fibrinogen within $5 \mathrm{~min}$, followed by $\mathrm{B} \beta$-chain degradation, in $30 \mathrm{~min}$, leaving the $\gamma$ chain unaffected after $60 \mathrm{~min}$ of incubation (Figure 4(a)). Concomitant with the $\mathrm{A} \alpha$ and $\mathrm{B} \beta$ chains partial digestion, degradation products were observed. Thus, the SDS-PAGE analysis (under reducing conditions) of this proteolytic process demonstrated that Bmoo FIBMP-I is an $\alpha$-fibrinogenase.

The optimal temperature (data not shown) and $\mathrm{pH}$ conditions for $\mathrm{A} \alpha$-chain digestion was $37^{\circ} \mathrm{C}$ and $6.0-$ 10.0 , respectively (Figure $4(\mathrm{~b})$ ). Hydrolysis of the $\mathrm{A} \alpha$ and $\mathrm{B} \beta$ chains was partially inhibited by EDTA, a standard metalloproteinase inhibitor, and not by aprotinin, a serinoproteinase inhibitor (data not shown). This result confirmed that Bmoo FIBMP-I is a metalloproteinase, since it was inhibited by a chelating agent, such as EDTA.

The lack of blood coagulation observed in many envenomation circumstances is caused by the degradation of fibrinogen by fibrinogenolytic enzymes that cause defibrination in vivo [59]. Bmoo FIBMP-I degraded fibrinogen in vitro, although it did not prevent coagulation in vivo. This can be explained by the presence of endogenous inhibitors, which are able to neutralize the proteolytic activity of snake venom proteases, such as $\alpha 2$-macroglobulin [59].
Bmoo FIBMP-I can be compared to a nonhaemorrhagic enzyme named neuwidase identified in the $B$. neuwiedi venom by Rodrigues et al. [19] and Izidoro et al. [60]. This enzyme is described as a metalloproteinase with preferential activity towards the A $\alpha$ chain of bovine fibrinogen and significantly less activity towards the $\mathrm{B} \beta$ chain. Another fibrinogenolytic enzyme identified was brevilysin L6, from Agkistrodon halys brevicaudus snake venom [61, 62], which has a molecular weight of 22,713, with 203 amino acid residues.

Besides these fibrinogenases, an enzyme of $24 \mathrm{kDa}$, designated Lachesis stenophrys fibrinogenase was isolated from Lachesis stenophrys snake venom and classified as class PI metalloproteinase which displays fibrinogenolytic activity, but lacks haemorrhagic activity [4].

Bmoo FIBMP-I can also be compared to the enzyme fibrolase, a zinc-dependent metalloproteinase, formed by a single chain of $23 \mathrm{kDa}$ [63], with the N-terminal blocked by a pyroglutamate residue that is present in both isoforms [48]. This enzyme has preferential proteolytic activity towards the $\alpha$ chain of bovine fibrinogen (cleavage site between Lys $^{413}$-Leu ${ }^{414}$ residues), a lower activity on the B $\beta$ chain [64] and no activity on the $\gamma$ chain. Recent advances following prospective studies with snake venoms suggest a therapeutic application of fibrinogenolytic metalloproteinase in the treatment of occlusive thrombosis $[65,66]$. Several of these enzymes have been studied in vivo in animal models and promising results have emerged $[46,65,67-74]$. 


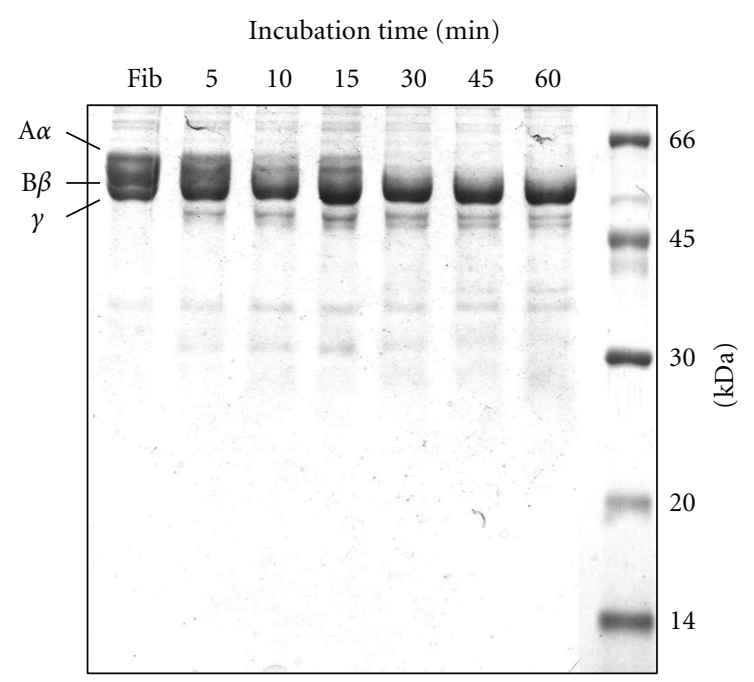

(a)

$\mathrm{pH}$ Influence

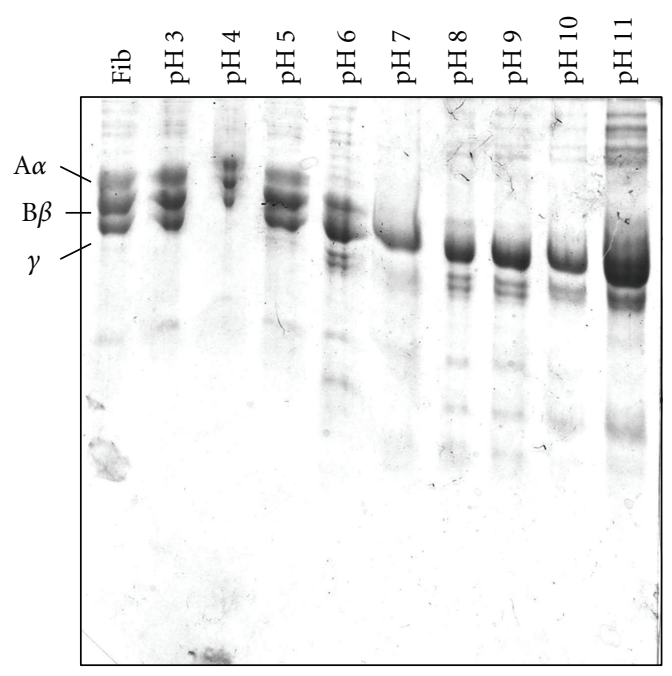

(b)

FIgURe 4: Fibrinogenolytic activities. (a) Bmoo FIBMP-I incubated with fibrinogen at different times $(5,10,15,30,45$, and $60 \mathrm{~min}), \mathrm{pH}$ 7.8 at $37^{\circ} \mathrm{C}$. Fibrinogen control incubated (without Bmoo FIBMPI) for $60 \mathrm{~min}$ is showed in the lane on the left. Molecular mass standards are shown in the lane on the right. (b) Bmoo FIBMP-I incubated with fibrinogen at different $\mathrm{pHs}(3,4,5,6,7,8,9$, 10, and 11), for $60 \mathrm{~min}$ at $37^{\circ} \mathrm{C}$.

Bmoo FIBMP-I showed proteolytic activity on azocasein and this activity was dependent on the $\mathrm{pH}$ and enzyme concentration, optimally occurring between $\mathrm{pH}$ 6-10.0 and being absent in acidic $\mathrm{pH}(3,4$, and 5$)$ and alkaline $\mathrm{pH}(11.0)$. Considering our data and other tests of proteolysis using azocasein $[39,75,76]$, one may conclude that the optimal $\mathrm{pH}$ for the proteolytic tests would be 8.8 . Many proteases have the proteolytic activity on azocasein reduced, but not completely abolished, when incubated at $\mathrm{pH}$ 5.0, and these proteases have higher activity in alkaline $\mathrm{pH}$ and are inactive at acidic $\mathrm{pH}$ values $[76,77]$.

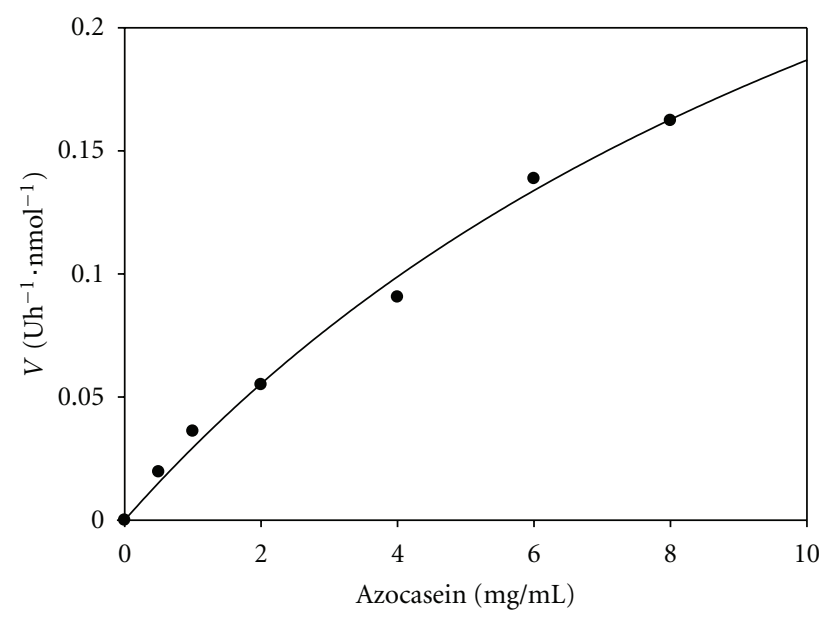

Figure 5: Michaelis-Menten plot of normalized velocity versus azocasein concentration. Each point represents the mean of two determinations. Statistic parameters: $r^{2}=0.9931 ; N=7 ; P<$ 0.0001 .

The proteolytic activity was assayed with different azocasein concentrations. The data were plotted as a MichaelisMenten type plot (Figure 5), and the regression line $\left(r^{2}=\right.$ $0.9931)$ lets us determine the $V_{\max }=0.4596 \mathrm{U} \mathrm{h}^{-1} \mathrm{nmoL}^{-1} \pm$ 0.1031 and $K_{m}=14.59 \mathrm{mg} / \mathrm{mL} \pm 4.610$.

\section{Conclusion}

In conclusion, we have purified a metalloproteinase, named Bmoo FIBMP-I, with azocaseinolytic and fibrinogenolytic activities, from $B$. moojeni venom. The properties of Bmoo FIBMP-I indicate that this protein belongs to class PI-B of SVMPs. These features suggest that this toxin could interfere with the coagulation cascade that follows envenoming. The cleavage specificity of Bmoo FIBMP-I for fibrinogen raises the possibility of using this enzyme in formulations for clinical use.

\section{Conflict of Interests}

There is no conflict of interests among the authors of this paper.

\section{Acknowledgments}

The authors thank Mrs. Flávia De Marco Almeida for helping in the writing of this paper. This work was supported by Grants from CAPES, CNPq, FAPEMIG, and INCTTOXFAPESP. F. S. Torres is supported by Toxinology CAPES Postdoctoral fellowship.

\section{References}

[1] F. S. Markland, "Snake venoms and the hemostatic system," Toxicon, vol. 36, no. 12, pp. 1749-1800, 1998.

[2] C. A. Bello, A. L. N. Hermogenes, A. Magalhaes et al., "Isolation and biochemical characterization of a fibrinolytic 
proteinase from Bothrops leucurus (white-tailed jararaca) snake venom," Biochimie, vol. 88, no. 2, pp. 189-200, 2006.

[3] D. Mebs and T. Langeluddeke, "European viper venoms: haemorrhagic and myotoxic activities," Toxicon, vol. 30, no. 10, pp. 1303-1306, 1992.

[4] A. Leonardi, F. Aragon-Ortiz, F. Gubenšek, and I. Križaj, "Partial primary structure of a fibrinogenase from the venom of the snake Lachesis stenophrys," Journal of Chromatography A, vol. 852, no. 1, pp. 237-243, 1999.

[5] J. B. Bjarnason and J. W. Fox, "Snake venom metalloendopeptidases: reprolysins," Methods in Enzymology, vol. 248, pp. 345368, 1995.

[6] J. W. Fox and S. M. T. Serrano, "Structural considerations of the snake venom metalloproteinases, key members of the M12 reprolysin family of metalloproteinases," Toxicon, vol. 45, no. 8, pp. 969-985, 2005.

[7] J. W. Fox and S. M. T. Serrano, "Insights into and speculations about snake venom metalloproteinase (SVMP) synthesis, folding and disulfide bond formation and their contribution to venom complexity," FEBS Journal, vol. 275, no. 12, pp. 3016-3030, 2008.

[8] O. H. P. Ramos and H. S. Selistre-De-Araujo, "Snake venom metalloproteases - structure and function of catalytic and disintegrin domains," Comparative Biochemistry and Physiology C, vol. 142, no. 3-4, pp. 328-346, 2006.

[9] W. J. Wang, C. H. Shih, and T. F. Huang, "Primary structure and antiplatelet mechanism of a snake venom metalloproteinase, acurhagin, from Agkistrodon acutus venom," Biochimie, vol. 87, no. 12, pp. 1065-1077, 2005.

[10] M. T. Assakura, C. A. Silva, R. Mentele, A. C. M. Camargo, and S. M. T. Serrano, "Molecular cloning and expression of structural domains of bothropasin, a P-III metalloproteinase from the venom of Bothrops jararaca," Toxicon, vol. 41, no. 2, pp. 217-227, 2003.

[11] M. Maruyama, M. Sugiki, E. Yoshida, H. Mihara, and N. Nakajima, "Purification and characterization of two fibrinolytic enzymes from Bothrops jararaca (jararaca) venom," Toxicon, vol. 30, no. 8, pp. 853-864, 1992.

[12] M. Maruyama, M. Sugiki, K. Anai, and E. Yoshida, "Nterminal amino acid sequences and some characteristics of fibrinolytic/hemorrhagic metalloproteinases purified from Bothrops jararaca venom," Toxicon, vol. 40, no. 8, pp. 12231226, 2002.

[13] M. T. Assakura, A. P. Reichl, M. C. Asperti, and F. R. Mandelbaum, "Isolation of the major proteolytic enzyme from the venom of the snake Bothrops moojeni (Caissaca)," Toxicon, vol. 23, no. 4, pp. 691-706, 1985.

[14] S. M. T. Serrano, M. F. C. Matos, F. R. Mandelbaum, and C. A. M. Sampaio, "Basic proteinases from Bothrops moojeni (Caissaca) venom-I. Isolation and activity of two serine proteinases, MSP 1 and MSP 2, on synthetic substrates and on platelet aggregation," Toxicon, vol. 31, no. 4, pp. 471-481, 1993.

[15] S. M. T. Serrano, C. A. M. Sampaio, and F. R. Mandelbaum, "Basic proteinases from Bothrops moojeni (caissaca) venomII. Isolation of the metalloproteinase MPB. Comparison of the proteolytic activity on natural substrates by MPB, MSP 1 and MSP 2," Toxicon, vol. 31, no. 4, pp. 483-492, 1993.

[16] C. P. Bernardes, N. A. Santos-Filho, T. R. Costa et al., "Isolation and structural characterization of a new fibrin(ogen)olytic metalloproteinase from Bothrops moojeni snake venom," Toxicon, vol. 51, no. 4, pp. 574-584, 2008.
[17] M. S. R. Gomes, M. M. Mendes, F. de Oliveira et al., "BthMP: a new weakly hemorrhagic metalloproteinase from Bothrops moojeni snake venom," Toxicon, vol. 53, no. 1, pp. 24-32, 2009.

[18] P. K. Akao, C. C. C. Tonoli, M. S. Navarro et al., "Structural studies of BmooMP $\alpha$-I, a non-hemorrhagic metalloproteinase from Bothrops moojeni venom," Toxicon, vol. 55, no. 2-3, pp. 361-368, 2010.

[19] V. M. Rodrigues, A. M. Soares, R. Guerra-Sá, V. Rodrigues, M. R. M. Fontes, and J. R. Giglio, "Structural and functional characterization of neuwiedase, a nonhemorrhagic fibrin(ogen)olytic metalloprotease from Bothrops neuwiedi snake venom," Archives of Biochemistry and Biophysics, vol. 381, no. 2, pp. 213-224, 2000.

[20] C. Baldo, I. Tanjoni, I. R. León et al., "BnP1, a novel P-I metalloproteinase from Bothrops neuwiedi venom: biological effects benchmarking relatively to jararhagin, a P-III SVMP," Toxicon, vol. 51, no. 1, pp. 54-65, 2008.

[21] D. S. Lopes, C. Baldo, C. de Freitas Oliveira et al., "Characterization of inflammatory reaction induced by neuwiedase, a PI metalloproteinase isolated from Bothrops neuwiedi venom," Toxicon, vol. 54, no. 1, pp. 42-49, 2009.

[22] A. Magalhães, H. P. B. Magalhães, M. Richardson et al., "Purification and properties of a coagulant thrombin-like enzyme from the venom of Bothrops leucurus," Comparative Biochemistry and Physiology A, vol. 146, no. 4, pp. 565-575, 2007.

[23] E. F. Sanchez, L. M. Gabriel, S. Gontijo et al., "Structural and functional characterization of a P-III metalloproteinase, leucurolysin-B, from Bothrops leucurus venom," Archives of Biochemistry and Biophysics, vol. 468, no. 2, pp. 193-204, 2007.

[24] S. Marcussi, C. P. Bernardes, N. A. Santos-Filho et al., "Molecular and functional characterization of a new nonhemorrhagic metalloprotease from Bothrops jararacussu snake venom with antiplatelet activity," Peptides, vol. 28, no. 12, pp. 2328-2339, 2007.

[25] M. V. Mazzi, S. Marcussi, G. B. Carlos et al., "A new hemorrhagic metalloprotease from Bothrops jararacussu snake venom: isolation and biochemical characterization," Toxicon, vol. 44, no. 2, pp. 215-223, 2004.

[26] M. V. Mazzi, A. J. Magro, S. F. Amui et al., "Molecular characterization and phylogenetic analysis of BjussuMP-I: a RGD-P-III class hemorrhagic metalloprotease from Bothrops jararacussu snake venom," Journal of Molecular Graphics and Modelling, vol. 26, no. 1, pp. 69-85, 2007.

[27] J. Gutiérrez, M. Romero, C. Díaz, G. Borkow, and M. Ovadia, "Isolation and characterization of a metalloproteinase with weak hemorrhagic activity from the venom of the snake Bothrops asper (terciopelo)," Toxicon, vol. 33, no. 1, pp. 19-29, 1995.

[28] A. Franceschi, A. Rucavado, N. Mora, and J. M. Gutiérrez, "Purification and characterization of $\mathrm{BaH} 4$, a hemorrhagic metalloproteinase from the venom of the snake Bothrops asper," Toxicon, vol. 38, no. 1, pp. 63-77, 2000.

[29] Y. A. Senis, P. Y. Kim, G. L. J. Fuller et al., "Isolation and characterization of cotiaractivase, a novel low molecular weight prothrombin activator from the venom of Bothrops cotiara," Biochimica et Biophysica Acta, vol. 1764, no. 5, pp. 863-871, 2006.

[30] N. A. Santos-Filho, L. B. Silveira, C. Z. Oliveira et al., "A new acidic myotoxic, anti-platelet and prostaglandin $\mathrm{I} 2$ inductor phospholipase $\mathrm{A}_{2}$ isolated from Bothrops moojeni snake venom," Toxicon, vol. 52, no. 8, pp. 908-917, 2008.

[31] R. F. Itzhaki and D. M. Gill, "A micro-biuret method for estimating proteins," Analytical Biochemistry, vol. 9, no. 4, pp. 401-410, 1964. 
[32] U. K. Laemmli, "Cleavage of structural proteins during the assembly of the head of bacteriophage T4," Nature, vol. 227, no. 5259 , pp. 680-685, 1970.

[33] A. Henschen, "Analysis of cysteine residues, disulfide bridges, and sulfydryl groups in proteins," in Advanced Methods in Protein Microsequence Analysis, B. Wittmann-Liebold, J. Salnikow, and V. A. Erdmann, Eds., pp. 244-255, Springer, Berlin, Germany, 1986.

[34] M. Richardson, A. M. C. Pimenta, M. P. Bemquerer et al., "Comparison of the partial proteomes of the venoms of Brazilian spiders of the genus Phoneutria," Comparative Biochemistry and Physiology C, vol. 142, no. 3-4, pp. 173-187, 2006.

[35] W. Edgar and C. R. M. Prentice, "The proteolytic action of ancrod on human fibrinogen and its polypeptide chains," Thrombosis Research, vol. 2, no. 1, pp. 85-95, 1973.

[36] H. Kondo, S. Kondo, H. Ikezawa, R. Murata, and A. Ohsaka, "Studies on the quantitative method for determination of hemorrhagic activity of habu snake venom," Japanese Journal of Medical Science \& Biology, vol. 13, pp. 43-51, 1960.

[37] R. D. G. Theakston and H. A. Reid, "Development of simple standard assay procedures for the characterization of snake venoms," Bulletin of the World Health Organization, vol. 61, no. 6, pp. 949-956, 1983.

[38] J. A. Gene, A. Roy, G. Rojas, J. M. Gutierrez, and L. Cerdas, "Comparative study on coagulant, defibrinating, fibrinolytic and fibrinogenolytic activities of Costa Rican crotaline snal venoms and their neutralization by a polyvalent antivenom," Toxicon, vol. 27, no. 8, pp. 841-848, 1989.

[39] A. Leonardi, F. Gubenseek, and I. Frizaj, "Purification and characterisation of two hemorrhagic metalloproteinases from the venom of the long-nosed viper, Vipera ammodytes ammodytes," Toxicon, vol. 40, no. 1, pp. 55-62, 2002.

[40] B. Rates, K. K. F. Ferraz, M. H. Borges, M. Richardson, M. E. De Lima, and A. M. C. Pimenta, "Tityus serrulatus venom peptidomics: assessing venom peptide diversity," Toxicon, vol. 52, no. 5, pp. 611-618, 2008.

[41] J. M. Gutiérrez and A. Rucavado, "Snake venom metalloproteinases: their role in the pathogenesis of local tissue damage," Biochimie, vol. 82, no. 9-10, pp. 841-850, 2000.

[42] G. L. Zaganelli, M. G. M. Zaganelli, A. Magalhães, C. R. Diniz, and M. E. De Lima, "Purification and characterization of a fibrinogen-clotting enzyme from the venom of jararacucu (Bothrops jararacussu)," Toxicon, vol. 34, no. 7, pp. 807-819, 1996.

[43] A. Lobo de Araújo, J. L. Donato, and C. Bon, "Purification and characterization of two hemorrhagic metalloproteinases from the venom of the long-nosed viper, Vipera ammodytes ammodytes," Toxicon, vol. 40, no. 1, pp. 55-92, 1998.

[44] M. B. Smolka, S. Marangoni, B. Oliveira, and J. C. Novello, "Purification and partial characterization of a thrombin-like enzyme, balterobin, from the venom of Bothrops alternatus," Toxicon, vol. 36, no. 7, pp. 1059-1063, 1998.

[45] H. C. Castro, D. L. S. Dutra, and A. L. Oliveira-Carvalho, "Bothroalternin, a trombin inhibitor from the venom of Bothrops alternatus," Toxicon, vol. 29, article 1279, 1998.

[46] F. Oliveira, V. M. Rodrigues, M. H. Borges et al., "Purification and partial characterization of a new proteolytic enzyme from the venom of Bothrops moojeni (Caissaca)," Biochemistry and Molecular Biology International, vol. 47, no. 6, pp. 1069-1077, 1999.

[47] A. M. Soares, S. H. Andrião-Escarso, Y. Angulo et al., "Structural and functional characterization of myotoxin I, a Lys49 phospholipase $\mathrm{A}_{2}$ homologue from Bothrops moojeni
(Caissaca) snake venom," Archives of Biochemistry and Biophysics, vol. 373, no. 1, pp. 7-15, 2000.

[48] S. L. Loayza, M. Trikha, F. S. Markland, P. Riquelme, and J. Kuo, "Resolution of isoforms of natural and recombinant fibrolase, the fibrinolytic enzyme from Agkistrodon contortrix contortrir snake venom, and comparison of their EDTA sensitivities," Journal of Chromatography B, vol. 662, no. 2, pp. 227-243, 1994.

[49] E. F. Sanchez, C. T. Souza, C. A. Bello, M. Richardson, E. B. Oliveira, and A. Magalhaes, "Resolution of isoforms of mutalysin II, the metalloproteinase from bushmaster snake venom," Toxicon, vol. 41, no. 8, pp. 1021-1031, 2003.

[50] R. N. Ferreira, B. Rates, M. Richardson et al., "Complete amino-acid sequence, crystallization and preliminary $\mathrm{X}$-ray diffraction studies of leucurolysin-a, a nonhaemorrhagic metalloproteinase from Bothrops leucurus snake venom," Acta Crystallographica Section F, vol. 65, no. 8, pp. 798-801, 2009.

[51] O. H. Jeon and D. S. Kim, "Molecular cloning and functional characterization of a snake venom metalloprotease," European Journal of Biochemistry, vol. 263, no. 2, pp. 526-533, 1999.

[52] E. F. Sanchez, C. R. Diniz, and M. Richardson, "The complete amino acid sequence of the haemorrhagic factor LHFI, a metalloproteinase isolated from the venom of the Bushmaster snake (Lachesis muta muta)," FEBS Letters, vol. 282, no. 1, pp. 178-182, 1991.

[53] T. Matsui, Y. Fujimura, and K. Titani, "Snake venom proteases affecting hemostasis and thrombosis," Biochimica et Biophysica Acta, vol. 1477, no. 1-2, pp. 146-156, 2000.

[54] J. B. Bjarnason and J. W. Fox, "Hemorrhagic metalloproteinases from snake venoms," Pharmacology and Therapeutics, vol. 62, no. 3, pp. 325-372, 1994.

[55] S. Herrick, O. Blanc-Brude, A. Gray, and G. Laurent, "Fibrinogen," The International Journal of Biochemistry \& Cell Biology, vol. 31, no. 7, pp. 741-746, 1999.

[56] W. Stocker, F. Grams, U. Baumann et al., "The metzincinstopological and sequential relations between the astacins, adamalysins, serralysins, and matrixins (collagenases) define a superfamily of zinc-peptidases," Protein Science, vol. 4, no. 5, pp. 823-840, 1995.

[57] Z. Z. Sapru, A. T. Tu, and G. S. Bailey, "Purification and characterization of a fibrinogenase from the venom of western diamondback rattlesnakes (Crotalus atrox)," Biochimica et Biophysica Acta, vol. 747, no. 3, pp. 225-231, 1983.

[58] T. F. Huang, J. H. Chang, and C. Ouyang, "Characterization of hemorrhagic principles from Trimeresurus gramineus snake venom," Toxicon, vol. 22, no. 1, pp. 45-52, 1984.

[59] E. N. Baramova, J. D. Shannon, J. B. Bjarnason, S. L. Gonias, and J. W. Fox, "Interaction of hemorrhagic metalloproteinases with human $\alpha 2$-macroglobulin," Biochemistry, vol. 29, no. 4, pp. 1069-1074, 1990.

[60] L. F. M. Izidoro, V. M. Rodrigues, R. S. Rodrigues et al., "Neutralization of some hematological and hemostatic alterations induced by neuwiedase, a metalloproteinase isolated from Bothrops neuwiedi pauloensis snake venom, by the aqueous extract from Casearia mariquitensis (Flacourtiaceae)," Biochimie, vol. 85, no. 7, pp. 669-675, 2003.

[61] W. Stocker, F. X. Gomis-Ruth, W. Bode, and R. Zwilling, "Implications of the three-dimensional structure of astacin for the structure and function of the astacin family of zincendopeptidases," European Journal of Biochemistry, vol. 214, no. 1, pp. 215-231, 1993.

[62] W. Bode, F. Grams, P. Reinemer et al., "The metzincin-superfamily of zinc-peptidases," Advances in Experimental Medicine and Biology, vol. 389, pp. 1-11, 1996. 
[63] A. L. Guan, A. D. Retzios, G. N. Henderson, and F. S. Markland, "Purification and characterization of a fibrinolytic enzyme from venom of the southern copperhead snake (Agkistrodon contortrix contortrix)," Archives of Biochemistry and Biophysics, vol. 289, no. 2, pp. 197-207, 1991.

[64] A. D. Retzios and F. S. Markland, "A direct-acting fibrinolytic enzyme from the venom of Agkistrodon contortrix contortrix: effects on various components of the human blood coagulation and fibrinolysis systems," Thrombosis Research, vol. 52, no. 6, pp. 541-552, 1988.

[65] C. F. Toombs, "Alfimeprase: pharmacology of a novel fibrinolytic metalloproteinase for thrombolysis," Haemostasis, vol. 31, no. 3-6, pp. 141-147, 2001.

[66] C. F. Toombs, "New directions in thrombolytic therapy," Current Opinion in Pharmacology, vol. 1, no. 2, pp. 164-168, 2001.

[67] V. J. Marder and S. Sherry, "Thrombolytic therapy: current status," The New England Journal of Medicine, vol. 318, no. 24, pp. 1585-1595, 1988.

[68] F. S. Markland, J. J. Bookstein, and T. Machado, "In vivo fibrinolytic activity of fibrolase, a metalloproteinase from the venom of Agkistrodon contortrix contortrix," Thrombosis and Haemostasis, vol. 62, article 121, 1989.

[69] T. W. Willis, A. T. Tu, and C. W. Miller, "Thrombolysis with a snake venom protease in a rat model of venous thrombosis," Thrombosis Research, vol. 53, no. 1, pp. 19-29, 1989.

[70] N. K. Ahmed, R. R. Gaddis, K. D. Tennant, and J. P. Lacz, "Biological and thrombolytic properties of fibrolase-a new fibrinolytic protease from snake venom," Haemostasis, vol. 20, no. 6, pp. 334-340, 1990.

[71] H. Abel, "Thrombolysis: the logical approach for the treatment of vascular occlusions," Acta Cardiologica, vol. 47, no. 4, pp. 287-295, 1992.

[72] M. Verstraete, H. R. Lijnen, and D. Collen, "Thrombolytic agents in development," Drugs, vol. 50, no. 1, pp. 29-42, 1995.

[73] N. A. Marsh and T. L. Fyffe, "Practical applications of snake venom toxins in haemostasis," Bollettino della Società Italiana di Biologia Sperimentale, vol. 72, no. 9-10, pp. 263-278, 1996.

[74] A. Gasmi, A. Chabchoub, S. Guermazi, H. Karoui, M. Elayeb, and K. Dellagi, "Further characterization and thrombolytic activity in a rat model of a fibrinogenase from Vipera lebetina venom," Thrombosis Research, vol. 86, no. 3, pp. 233-242, 1997.

[75] E. S. Garcia, J. A. Guimaraes, and J. L. Prado, "Purification and characterization of a sulfhydryl-dependent protease from Rhodnius prolixus midgut," Archives of Biochemistry and Biophysics, vol. 188, no. 2, pp. 315-322, 1978.

[76] J. R. F. Sousa, R. Q. Monteiro, H. C. Castro, and R. B. Zingali, "Proteolytic action of Bothrops jararaca venom upon its own constituents," Toxicon, vol. 39, no. 6, pp. 787-792, 2001.

[77] S. Iwanaga and T. Suzuki, "Enzymes in snake venoms," in Snake Venom: Handbook of Experimental Pharmacology, C. Y. Lee, Ed., vol. 52, pp. 61-158, Springer, Berlin, Germany, 1979.

[78] S. Terada, J. Hori, S. Fujimura, and E. Kimoto, "Purification and amino acid sequence of brevilysin L6, a non-hemorrhagic metalloprotease from Agkistrodon halys brevicaudus venom," Journal of Biochemistry, vol. 125, no. 1, pp. 64-69, 1999. 

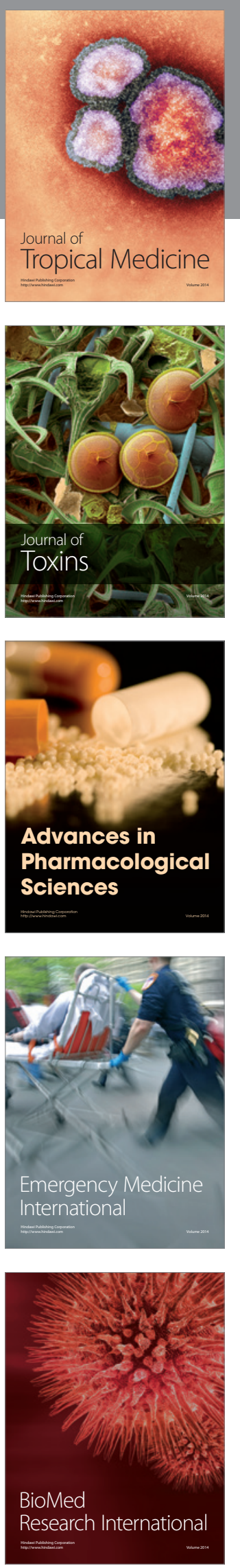
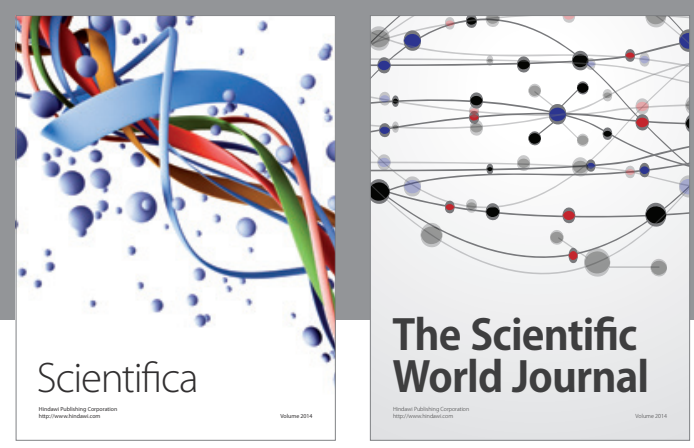

The Scientific World Journal
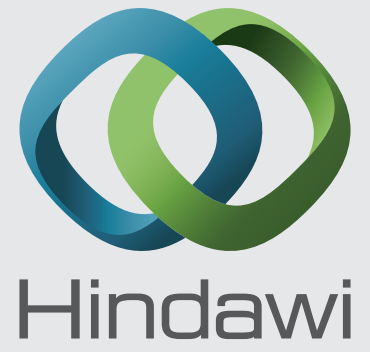

Submit your manuscripts at

http://www.hindawi.com
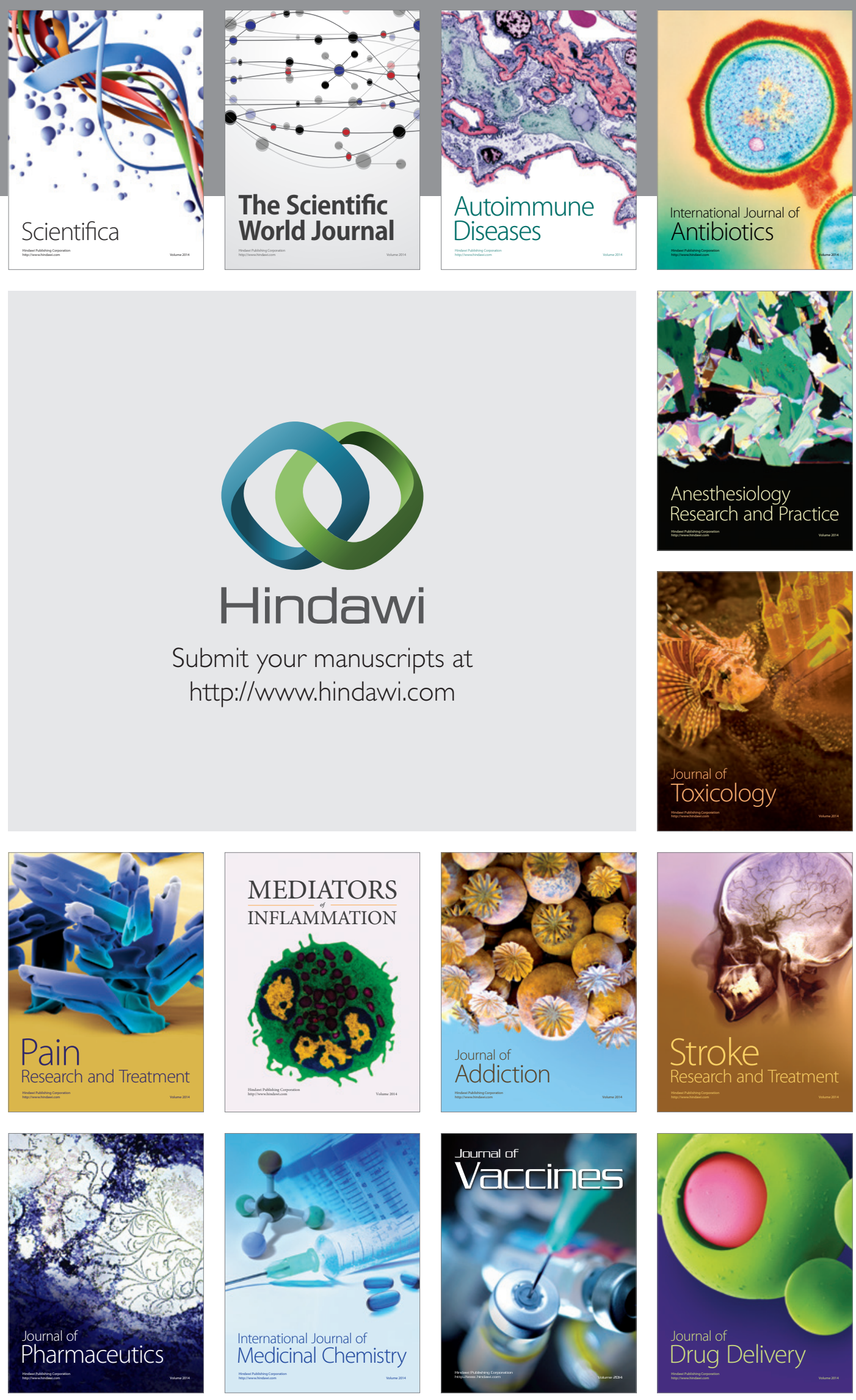